University of Nebraska - Lincoln

DigitalCommons@University of Nebraska - Lincoln

Development and Characterization of 15 Polymorphic Microsatellite Loci Isolated From Rafinesque's Big-Eared Bat, Corynorhinus rafinesquii

\author{
Antoinette J. Piaggio \\ USDA/APHIS/WS National Wildlife Research Center, Toni.J.Piaggio@aphis.usda.gov \\ Julia A. Figueroa \\ USDA-APHIS-Wildlife Services \\ Susan L. Perkins \\ Sackler Institute for Comparative Genomics, American Museum of Natural History
}

Follow this and additional works at: https://digitalcommons.unl.edu/icwdm_usdanwrc

Part of the Environmental Sciences Commons

\footnotetext{
Piaggio, Antoinette J.; Figueroa, Julia A.; and Perkins, Susan L., "Development and Characterization of 15 Polymorphic Microsatellite Loci Isolated From Rafinesque's Big-Eared Bat, Corynorhinus rafinesquii" (2009). USDA National Wildlife Research Center - Staff Publications. 953.

https://digitalcommons.unl.edu/icwdm_usdanwrc/953
}

This Article is brought to you for free and open access by the U.S. Department of Agriculture: Animal and Plant Health Inspection Service at DigitalCommons@University of Nebraska - Lincoln. It has been accepted for inclusion in USDA National Wildlife Research Center - Staff Publications by an authorized administrator of DigitalCommons@University of Nebraska - Lincoln. 


\title{
Development and characterization of 15 polymorphic microsatellite loci isolated from Rafinesque's big-eared bat, Corynorhinus rafinesquii
}

\author{
ANTOINETte J. PiAgGiO, ${ }^{*}$ JUliA A. FIGUEROA* and SUSAN L. PERKINS† \\ *USDA, Wildlife Services, National Wildlife Research Center, Wildlife Genetics Lab, 4101 LaPorte Avenue, Fort Collins, CO 80521, \\ USA, +Sackler Institute for Comparative Genomics, American Museum of Natural History, Central Park West at 79th Street, New York, \\ NY 10024, USA
}

\begin{abstract}
We developed and characterized 15 microsatellite markers for Rafinesque's big-eared bat, Corynorhinus rafinesquii. In a population from Tennessee, the number of alleles per locus ranged from three to 13 and observed heterozygosities were 0.35 to 0.97 per locus. These loci will provide appropriate variability for estimation of population connectivity, demographic parameters, and genetic diversity for this species of concern.
\end{abstract}

Keywords: Corynorhinus rafinesquii, microsatellite, Rafinesque's big-eared bat

Received 26 November 2008; accepted 25 January 2009

Rafinesque's big-eared bat, Corynorhinus rafinesquii (Vespertilionidae), is an endemic, monotypic species from the southeastern USA (Piaggio \& Perkins 2005). This bat is considered a federal species at risk (US Fish and Wildlife Service 1985), a species of concern in every state within its range, and is listed as endangered in Virginia. Currently, state and federal agencies are working towards developing an official conservation plan for this species, which includes critical research needs such as an evaluation of genetic diversity within populations of $C$. rafinesquii, estimation of population connectivity, and an assessment to determine if populations are experiencing expansion, contraction, or stability. The development of species-specific markers is crucial to accomplishing these goals. To this end, we have developed 15 autosomal microsatellite markers for this species. To assess the utility and variability of each marker, they were characterized using 31 C. rafinesquii individuals from southwestern Tennessee.

A C. rafinesquii individual from South Carolina was used for enrichment and development of a microsatellite library. This was achieved with an adapted method from Glenn \& Schable (2005). Following this protocol, genomic DNA was digested with $R s a I$ and these fragments were ligated using double-stranded SNX-24 linkers. The resulting library was hybridized to 12 biotinylated microsatellite oligonucleotide

Correspondence: Antoinette J. Piaggio, USDA/APHIS/WS/ National Wildlife Research Center, Wildlife Genetics Lab, 4101 LaPorte Avenue, Ft. Collins, CO 80521. Fax: (970) 266 6098; E-mail: toni.j.piaggio@aphis.usda.gov probes with dinucleotide and trinucleotide repeats (e.g. CT, CA, AAG and GGA). Hybridized fragments were captured on streptavidin-coated Dynabeads (Dynal Biotech). These fragments were then amplified and cloned with the TOPO TA cloning kit (Invitrogen). Insert sequences from 96 colonies were obtained with M13 forward and reverse primers and run on an ABI 3730xl genetic analyzer (Applied Biosystems). Forty-seven clone sequences had recognizable microsatellite sequences, of which $87 \%$ (41) had enough or adequate flanking regions to design primers. Staden Package (Staden et al. 1998), TROLL (Castelo et al. 2002; Martins et al. 2006), and Primer 3 (Rozen \& Skaletsky 2000) software packages were utilized to detect repeat regions and design primers within flanking regions. Parameters for Staden software were set according to step-by-step instructions included on the website for TROLL software. Forty-one primer pairs were designed and tested; 15 pairs amplified and were variable.

M13 primer sequences were added to the $5^{\prime}$ end of each forward primer. M13 primers were labelled with NED, FAM, or HEX. M13, forward and reverse primers were ordered from Applied Biosystems (ABI). Polymerase chain reactions (PCR) were carried out in a $10-\mu \mathrm{L}$ reaction using $1.0 \mu \mathrm{L}$ of genomic DNA, $0.5-0.9 \mu \mathrm{L}$ each of $1 \mu \mathrm{M}$ primer (Table 1 ), $1.0 \mu \mathrm{L}$ of $10 \mathrm{~mm}$ dNTP (Promega), $0.2 \mu \mathrm{L}$ of Taq DNA polymerase (Promega), $0.4 \mu \mathrm{L}$ or $0.5 \mu \mathrm{L}$ (Cora_G02_E04) $5 \mathrm{mg} / \mathrm{mL}$ BSA (Invitrogen), and locus-specific chemistry listed in Table 2. All PCRs were conducted using a Mastercycler Gradient thermacycler (Eppendorf, Germany). The thermal profile (Table 2) for all loci was an initial denaturation at $94^{\circ} \mathrm{C}$ for $3-5 \mathrm{~min}$ followed by $35-40$ cycles of $94^{\circ} \mathrm{C}$ for $30 \mathrm{~s}$, 
Table 1 Characteristics of the 15 microsatellite loci that were developed and optimized from Corynorhinus rafinesquii

\begin{tabular}{|c|c|c|c|c|c|c|}
\hline Locus & Primer sequence $\left(5^{\prime}-3^{\prime}\right) ; F$, forward; $R$, reverse & Repeat motif & Size range (bp) & $N_{\mathrm{A}}$ total & $H_{\mathrm{O}}$ & $H_{\mathrm{E}}$ \\
\hline Cora_B07_H12 & $\begin{array}{l}\text { F: TTAGACAAATGAGGGAGGATTG } \\
\text { R: CATCAAAGAATGCCAAACTAAAG }\end{array}$ & $(\mathrm{AG})_{19}$ & $271-313$ & 11 & 0.97 & 0.89 \\
\hline Cora_F $F_{11} \_$C04 & $\begin{array}{l}\text { F: AAGCTCAGAGACTGCTCCTTC } \\
\text { R: ATCCATTATGTTTGCTGATGTTC }\end{array}$ & $(\mathrm{TG})_{8} \ldots(\mathrm{TG})_{17}$ & $186-220$ & 9 & 0.84 & 0.81 \\
\hline Cora_D12_D12 & $\begin{array}{l}\text { F: CATAAAGGAGACAACAAATCAATG } \\
\text { R: CAGAGAGAGAAAGAAAGGGAAAG }\end{array}$ & $(\mathrm{TC})_{7}$ & 110-114 & 3 & 0.35 & 0.40 \\
\hline Cora_C05_E01 & $\begin{array}{l}\text { F: GCCTCTCTCATATCAATGTGTGT } \\
\text { R: GCAGTTAGAGGAAAACAGGCT }\end{array}$ & $(\mathrm{TG})_{6}$ & $287-293$ & 3 & 0.63 & 0.54 \\
\hline Cora_G02_E04 & $\begin{array}{l}\text { F: АCTCCTGAAAGTGCTGATGTTAT } \\
\text { R: TGTTTCTCTCTCATTGATGTTTC }\end{array}$ & $(\mathrm{CA})_{11}$ & $320-326$ & 4 & 0.52 & 0.52 \\
\hline Cora_E07_E07 & $\begin{array}{l}\text { F: TTACTAAAGGTTTGGGTAGGGAA } \\
\text { R: GTGAAGTAGCCTGGCCTAAGA }\end{array}$ & $(\mathrm{GC})_{9} \ldots(\mathrm{CA})_{12}$ & $163-179$ & 9 & 0.84 & 0.83 \\
\hline Cora_F02_F02 & $\begin{array}{l}\text { F: GTCACTGGCTACAAAGAATGAAG } \\
\text { R: GAAACACAGCAGAATTGTCTCTC }\end{array}$ & $(\mathrm{TC})_{24} \ldots(\mathrm{CA})_{25}$ & $201-263$ & 13 & 0.94 & 0.92 \\
\hline Cora_G04_F04 & $\begin{array}{l}\text { F: GAACATGCCACACAGAGACTTAC } \\
\text { R: CTAGACCTTCCCGTGTGTAAAG }\end{array}$ & $(G T)_{23}$ & $255-300$ & 13 & 0.71 & 0.85 \\
\hline Cora_C07_G01 & $\begin{array}{l}\text { F: CATTGGCTTTGTCTTAACAATTT } \\
\text { R: TTTGTTTCAGTTTCTCTCTCTCC }\end{array}$ & $(\mathrm{AG})_{14}$ & $191-213$ & 11 & 0.90 & 0.87 \\
\hline Cora_E10_G03 & $\begin{array}{l}\text { F: ACTTTTCATTCTTTCCCATTCT } \\
\text { R: AAACCAACGAGTGCTAAATCTAC }\end{array}$ & $(\mathrm{TG})_{26}$ & $333-357$ & 12 & 0.87 & 0.89 \\
\hline Cora_G10_A08 & $\begin{array}{l}\text { F: TTACAGTAGATACGGTTGTGCCT } \\
\text { R: TTTTAGGACTGGTTTTAGGGAAG }\end{array}$ & $(\mathrm{GT})_{21}$ & 259-277 & 7 & 0.84 & 0.73 \\
\hline Cora_D08_H02 & $\begin{array}{l}\text { F: TTCCCACTTTATTTCCTTTATCT } \\
\text { R: AAATCTATTTTCTCTACAACCAGAG }\end{array}$ & $(\mathrm{TC})_{15}$ & $332-354$ & 11 & 0.71 & 0.83 \\
\hline Cora_G11_H04 & $\begin{array}{l}\text { F: GAGATACAACTGGAAAGAGCTGA } \\
\text { R: TCGAAGACTTAAAAGCAATTTGA }\end{array}$ & $\begin{array}{l}(\mathrm{GA})_{9} \ldots(\mathrm{AG})_{6} \ldots(\mathrm{AG})_{6} \ldots(\mathrm{AG})_{6} \ldots \\
(\mathrm{AG})_{9}\end{array}$ & $202-222$ & 9 & 0.60 & $0.85^{*}$ \\
\hline Cora_H07_C05 & $\begin{array}{l}\text { F: TGATATGCACCTGAATTTCCTAC } \\
\text { R: GGAGATGCTTCTATGACTTGCTA }\end{array}$ & $(\mathrm{AC})_{22}$ & $335-347$ & 7 & 0.48 & $0.73^{*}$ \\
\hline Cora_H09_H09 & $\begin{array}{l}\text { F: ATTTATTCAGATGGAAATCAGCC } \\
\text { R: GAGTATCACCTACAGCCTCCTTT }\end{array}$ & $(\mathrm{AC})_{12} \ldots(\mathrm{AC})_{11}$ & $110-132$ & 8 & 0.87 & 0.85 \\
\hline
\end{tabular}

GenBank Accession nos FJ469632-FJ469646; $N_{\mathrm{A}}$, mean number of alleles per locus; $H_{\mathrm{O}}$, observed and $H_{\mathrm{E}}$, expected heterozygosities. The following loci had evidence of null alleles, null allele frequencies (in parentheses) are based on Brookfield1 estimates from Micro-Checker software;Cora_D12_D12 (0.03),Cora_G04_F04 (0.08),Cora_D08_H02 (0.06),Cora_G11_H04 (0.13), Cora_H07_C05 (0.14).*denotes violation of Hardy-Weinberg equilibrium and significant evidence of null alleles; these loci should not be used for population analyses in these populations but may be useful to test in other populations or species.

$52-54{ }^{\circ} \mathrm{C}$ for $30 \mathrm{~s}$, and $72{ }^{\circ} \mathrm{C}$ for $45 \mathrm{~s}$. Cycling was followed with either a 30 -min extension at $60^{\circ} \mathrm{C}$ or a 45 -min extension at $72{ }^{\circ} \mathrm{C}$ (Cora_C05_E01). For characterization of the markers, tissue samples were collected through wing biopsies (Wilmer \& Barratt 1996) from 31 C. rafinesquii from southwestern Tennessee. Samples were preserved in a $20 \%$ dimethyl sulfoxide, 0.25 м EDTA, saturated with $\mathrm{NaCl}$, pH 8.0 solution (Seutin et al. 1991). Genomic DNA was extracted from half of the biopsy using a DNeasy Tissue Extraction Kit (QIAGEN Inc.) following the manufacturer's protocol. Samples were genotyped on an ABI 3130 automated genetic analyzer and analyzed with ABI GeneMapper software.

Each locus was tested for null alleles with Micro-Checker (van Oosterhout et al. 2004). Hardy-Weinberg equilibrium tests and number of alleles were obtained from Arlequin 3.1 (Excoffier et al. 2005). Tests for genotypic disequilibrium between pairs of loci were performed using FSTAT 2.9.3 (Goudet 2001). There was evidence of null alleles in five loci at moderate rates (Table 1). However, only two loci demonstrated significant deviations from Hardy-Weinberg equilibrium (Table 1) after sequential Bonferroni correction (Rice 1989). These two loci,Cora_G11_H04 and Cora_H07F_C05R, should not be used in population-level analyses of these samples under the assumption that they suffer from a prevalence of null alleles. However, they may be useful for testing in other populations or species. The number of alleles per locus in the remaining loci ranged from three to 13 and observed heterozygosity ranged from 0.35 to 0.97 per locus (Table 1). There was no linkage disequilibrium between any pair of loci. The development of these markers provides a valuable tool for researchers to gain knowledge of C. rafinesquii population demographics. This is particularly 
Table 2 PCR conditions for each primer pair

\begin{tabular}{|c|c|c|c|c|c|}
\hline Marker & $\begin{array}{l}\text { Primer quantity for } \\
\text { PCR using } 1 \mu \mathrm{M} \text { primer } \\
\text { F,R/M13 }(\mu \mathrm{L})\end{array}$ & $\begin{array}{l}\text { Invitrogen } 5 \times \\
\text { buffer } C(\mu L)\end{array}$ & $\begin{array}{l}\text { Initial denaturation } \\
\text { time (min) }\end{array}$ & $\begin{array}{l}\text { Annealing } \\
\text { temperature }\left({ }^{\circ} \mathrm{C}\right)\end{array}$ & Cycles \\
\hline Cora_B07_H12 & $0.60 / 0.60$ & 3.3 & 3 & 52 & 40 \\
\hline Cora_ $F_{11}-C 04$ & $0.90 / 0.90$ & 3.3 & 3 & 52 & 35 \\
\hline Cora_D12_D12 & $0.50 / 0.50$ & 3.3 & 5 & 52 & 40 \\
\hline Cora_C05_E01 & $0.90 / 0.90$ & 3.4 & 5 & 52 & 40 \\
\hline Cora_G02_E04 & $0.90 / 0.80$ & 3.0 & 5 & 54 & 35 \\
\hline Cora_E07_E07 & $0.50 / 0.50$ & 3.3 & 3 & 52 & 35 \\
\hline Cora_F02_F02 & $0.90 / 0.90$ & 3.4 & 5 & 52 & 40 \\
\hline Cora_G04_F04 & $0.90 / 0.90$ & 3.1 & 3 & 53 & 35 \\
\hline Cora_C07_G01 & $0.80 / 0.80$ & 3.4 & 3 & 52 & 35 \\
\hline Cora_E10_G03 & $0.90 / 0.90$ & 3.3 & 3 & 52 & 35 \\
\hline Cora_G10_A08 & $0.80 / 0.80$ & 3.3 & 3 & 52 & 35 \\
\hline Cora_D08_H02 & $0.90 / 0.90$ & 3.3 & 3 & 52 & 35 \\
\hline Cora_G11_H04 & $0.90 / 0.90$ & 3.3 & 3 & 52 & 35 \\
\hline Cora_H07_C05 & $0.60 / 0.60$ & 3.3 & 5 & 52 & 40 \\
\hline Cora_H09_H09 & $0.50 / 0.50$ & 3.3 & 5 & 52 & 35 \\
\hline
\end{tabular}

useful for this species because there is tremendous concern about declining populations across its range.

\section{Acknowledgements}

We are indebted to Brian Carver, Biology Department, FreedHardeman University, and Frances Bennett for collecting samples. A.J.P. is supported by an Animal Plant Health Inspection Services Science Fellowship.

\section{References}

Castelo AT, Martins WS, Gao GR (2002) Tandem repeat occurrence locator. Bioinformatics, 8, 634-636.

Excoffier L, Laval G, Schneider S (2005) Arlequin ver. 3.0: an integrated software package for population genetics data analysis. Evolutionary Bioinformatics Online, 1, 47-50.

Glenn TC, Schable NA (2005) Isolating microsatellite DNA loci. Methods in Enzymology, 395, 202-222.

Goudet J (2001) FSTAT ver. 2.9.3, A program to estimate and test gene diversities and fixation indices (updated from Goudet 1995). University of Lausanne, Switzerland. http://www.unil.ch/ izea/softwares/fstat.html.

Martins W, de Sousa D, Proite K, Guimarães P, Moretzsohn M, Bertoli D (2006) New softwares for automated microsatellite marker development. Nucleic Acids Research, 34, E31.

Piaggio AJ, Perkins SL (2005) Molecular phylogeny of North American long-eared bats (Vespertilionidae: Corynorhinus); inter- and intraspecific relationships inferred from mitochon- drial and nuclear DNA sequences. Molecular Phylogenetics and Evolution, 37, 762-775.

Rice WR (1989) Analyzing tables of statistical tests. Evolution, 43, 223-225.

Rozen S, Skaletsky H (2000) Primer 3 on the WWW for general users and for biologist programmers. In: Bioinformatics Methods and Protocols: Methods in Molecular Biology (eds Krawetz S, Misener S), pp. 365-386. The Humana Press Inc, Totowa, New Jersey.

Seutin G, White BN, Boag PT (1991) Preservation of avian blood and tissue samples for DNA analyses. Canadian Journal of Zoology, 69, 82-90.

Staden R, Beal KF, Bonfield JK (1998) The Staden Package. In: Computer Methods in Molecular Biology, Bioinformatics Methods and Protocols (eds Misener S, Krawetz S), Vol. 132, pp. 115-130. The Humana Press Inc, Totowa, New Jersey.

US Fish and Wildlife Service (1985) Endangered and threatened wildlife and plants; animal candidate review for listing as endangered or threatened species. Federal Register, 50, 37965.

van Oosterhout C, Hutchison WF, Wills DPM, Shipley P (2004) Micro-Checker: software for identifying and correcting genotyping errors in microsatellite data. Molecular Ecology Notes, 4, 535.

Wilmer JW, Barratt E (1996) A non-lethal method of tissue sampling for genetic studies of chiropterans. Bat Research News, 37, 1-4.

doi: 10.1111/j.1755-0998.2009.02625.x

Published 2009. This article is a US Government work and is in the public domain in the USA. 